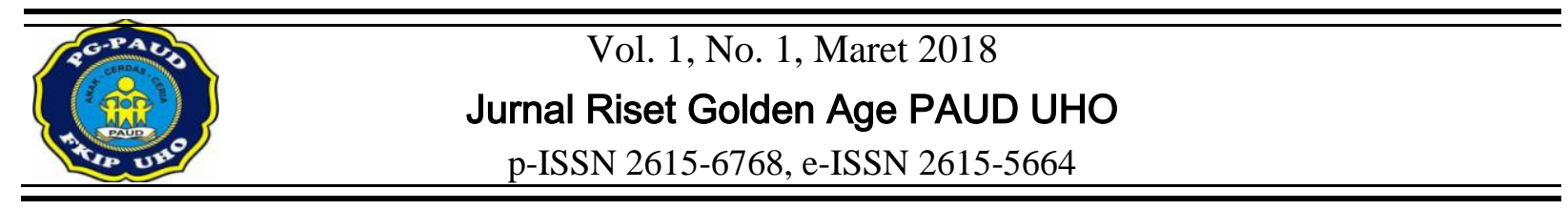

\title{
MENINGKATKAN KEMAMPUAN MOTORIK HALUS ANAK MELALUI KEGIATAN MENEMPEL PADA POLA DI KELOMPOK B TK NEGERI MELATI MEKAR KECAMATAN WOLASI
}

\author{
Sriwati $^{1)}$, Aisyah ${ }^{2)}$ \\ ${ }^{1}$ Alumni Jurusan PG-PAUD, Universitas Halu Oleo. Jln. H.E.A Mokodompit, Kendari 93232, \\ Indonesia. \\ ${ }^{2}$ Dosen Jurusan PG-PAUD, Universitas Halu Oleo. Jln. H.E.A Mokodompit, Kendari 93232, \\ Indonesia.
}

\begin{abstract}
Abstrak
Penelitian ini bertujuan untuk meningkatkan kemampuan motorik halus anak melalui kegiatan menempel pada pola di Kelompok B TK Negeri Melati Mekar Kecamatan Wolasi. Jenis penelitian ini adalah Penelitian Tindakan Kelas (PTK). Penelitian ini dilaksanakan dalam dua siklus. Tahap-tahap dalam penelitian ini mengikuti prosedur penelitian tindakan kelas, yaitu: perencanaan, pelaksanaan, pengamatan atau observasi, dan refleksi. Subjek dalam penelitian ini adalah guru dan anak di Kelompok B TK Negeri Melati Mekar Kecamatan Wolasi yang berjumlah 20 orang yang terdiri atas 8 orang anak laki-laki dan 12 orang anak perempuan. Hasil penelitian ini menunjukkan bahwa hasil belajar anak melalui kegiatan menempel pada pola menunjukkan bahwa terdapat peningkatan. Hal ini dapat ditunjukkan pada siklus I diperoleh keberhasilan anak mencapai persentase $60 \%$ dan pada siklus II diperoleh keberhasilan dengan persentase $85 \%$. Dengan demikian dapat disimpulkan bahwa kemampuan motorik halus anak di Kelompok B TK Negeri Melati Mekar dapat ditingkatkan melalui kegiatan menempel pada pola.
\end{abstract}

Kata kunci: Motorik Halus, Menempel, Pola.

\section{IMPROVING FINE MOTOR ABILITY OF CHILDREN THROUGH ACTIVITIES ATTACHED TO A PATTERN IN THE GROUP B TK NEGERI MELATI MEKAR WOLASI DISTRICT}

\begin{abstract}
This research aims to improve fine motor ability of children through activities attached to a pattern in the Group B TK Negeri Melati Mekar Wolasi District. This type of research this is a classroom action Research (PTK). This research was conducted in two cycles. The stages in this study followed research class action procedures, namely: planning, implementation, observation, and reflection. The subject in this study are the teachers and children in the Group B TK Negeri Jasmine Bloom Subdistrict Wolasi totalling 20 people comprising 8 boys and 12 girls. The results of this research show that the results of the study through the activities of the child clings to the pattern showed that there was increased. This can be shown in the cycle I gained the success of children reached $60 \%$ and the percentage on the cycle II obtained success with a percentage of $85 \%$. Thus it can be concluded that the fine motor ability of children in Group B TK Negeri Melati Mekar can be enhanced through the activities of the stick to the pattern.
\end{abstract}

Keywords: Fine Motor, Sticking, Pattern.

\section{PENDAHULUAN}

Undang-Undang Nomor 20 Tahun 2003 tentang sistem Pendidikan Nasional telah mengamanatkan dilaksanakannya pendidikan kepada seluruh rakyat Indonesia sejak usia dini, yakni sejak anak dilahirkan. Disebutkan secara tegas dalam Undang-Undang Tersebut bahwa pendidikan anak usia dini (PAUD) adalah suatu upaya pembinaan yang ditujukan kepada anak sejak lahir sampai dengan usia enam tahun yang dilakukan melalui pemberian rangsangan pendidikan untuk membantu pertumbuhan dan perkembangan jasmani dan rohani agar anak 
memiliki kesiapan dalam memasuki pendidikan lebih lanjut.

Masa usia dini merupakan masa anak yang sering dipandang sebagai masa keemasan bagi penyelenggara pendidikan dan hanya terjadi sekali dalam perkem-bangan kehidupan manusia. Masa golden age merupakan masa yang kritis dalam perkembangan anak, sehingga stimulasi atau rangsangan dari lingkungan sangat dibutuhkan untuk mengembangkan segala aspek perkembangan anak guna mencapai tahapan sesuai dengan tugas perkembangannya. Salah satu aspek yang harus dikembangkan dalam pendidikan anak usia dini adalah pengembangan motorik halus.

Keterampilan motorik halus sebaiknya sudah diperkenalkan kepada anak usia dini. Sebab kegiatan motorik halus merupakan langkah awal bagi pematangan dalam hal menggunting dan menempel. Anak-anak memerlukan persiapan yang matang sebelum mereka bersekolah, sehingga kelak diharapkan mereka mampu menguasai geraka-gerakan yang akan dilakukan nantinya pada saat bersekolah.

Motorik merupakan sekumpulan kemampuan untuk menggunakan dan mengontrol gerakan tubuh, baik gerakan kasar maupun gerakan halus. Kemampuan yang termasuk dalam aspek motorik ini adalah antara lain: mengangkat kepala, duduk. Merangkak, berdiri, berjalan, ber-lari, memegang benda kelenturan pergela-ngan tangan, menunjuk kesebuah titik, menggunakan jari penjepit, dan sebagainya. Kemampuan motorik selalu memerlukan kordinasi bagian-bagian tubuh, sehingga latihan untuk aspek motorik ini perlu diperhatikan (Yunanto, 2005: 8).

Kemampuan motorik adalah kemampuan untuk melakukan gerakan. Kemampuan motorik diawali dengan koordinasi tubuh, duduk, merangkak, berdiri dan diakhiri dengan berjalan. Kemampuan gerak ditentukan oleh perkembangan kekuatan otot, tulang, dan koordinasi otak untuk menjaga keseimbangan tubuh. Perkembangan kemampuan motorik merupakan perkembangan pengendalian gerakan jasmani yang terkoordinasi antara pusat syaraf, urat syaraf, dan otot

Perkembangan tersebut diawali dengan gerakan reflek sesaat setelah lahir diperlukan untuk bertahan hidup seperti mengisap, menelaan, berkedip, merenggutkan lutut, menggenggam ibu jari kaki dan menggenggam tangan. Gerakan reflek yang kurang berguna seperti reflek menggenggam ibu jari kaki dan reflek menggenggam tangan secara bertahap akan berkurang dan menghilang sebelum usia 1 tahun karena otak kecil (cerebellum) yang mengendalikan keseimbangan berkembang dengan cepat selama setahun awal kehidupan anak (Retno \& Danis, 2008: 20).

Motorik merupakan sekumpulan kemampuan untuk menggunakan dan mengontrol gerakan tubuh, baik gerakan kasar maupun gerakan halus. Kemampuan yang termasuk dalam aspek motorik ini adalah antara lain: mengangkat kepala, duduk. Merangkak, berdiri, berjalan, ber-lari, memegang benda kelenturan pergela-ngan tangan, menunjuk kesebuah titik, menggunakan jari penjepit, dan sebagainya. Kemampuan motorik selalu memerlukan kordinasi bagian-bagian tubuh, sehingga latihan untuk aspek motorik ini perlu diperhatikan (Yunanto, 2005: 8).

Perkembangan motorik merupakan proses memperoleh keterampilan dan pola gerakan yang dapat dilakukan anak, keterampilan motorik diperlukan untuk mengendalikan tubuh. Hildebrand (1986) mengemukakan dua macam keterampilan motorik yaitu keterampilan koordinasi otot halus dan keterampilan koordinasi otot kasar. Keterampilan koordinasi otot halus biasanya dipergunakan dalam kegiatan belajar di dalam ruangan, sedangkan keterampilan otot kasar dipergunakan di luar ruangan.

Pengembangan keterampilan motorik kasar meliputi kegiatan seluruh tubuh atau bagian tubuh. Dengan menggunakan bermacam koordinasi kelompok otot-otot tertentu anak dapat belajar untuk merangkak, melempar atau meloncat. Koordinasi keseimbangan, ketangkasan, kelenturan, kekuatan, kecepatan dan ketahanan merupakan kegiatan motorik kasar (Gardon, 1985). Pengembangan motorik halus merupakan kegiatan yang menggunakan otot halus pada kaki dan tangan. Gerakan ini memerlukan kecepatan, ketepatan, dan ketermpilan menggerakan. Selain itu keterampilan lain yang diperlukan adalah gerakan pengamatan yaitu bagaimana anak melakukan gerakan dalam mengamati suatu benda. Suatu gerakan dikatan berdaya guna dan berhasil guna lebih banyak ditentukan oleh kecepatan pengamatan anak sendiri dan lingkungan. Karena itu perkembangan pengamatan anak tergantung pada gerakan yang dilakukan.

Seefel dalam Hildebran (1986) membagikan keterampilan dalam tiga 
penggolongan yaitu keterampilan loko motorik, non lokomorik, keterampilan memproyeksi, menerima menggerakan dan menagkap benda. Keterampilan lokomorik terdiri atas berjalan, berlari, melompat, meloncat, merayap, meluncur, bergulung-gulung, berhenti, mulai berjalan, menjatuhkan diri, mengelak.

Keterampilan non lokomotor yaitu kemampuan menggerakan bagian tubuh dengan anak diam ditempat: berayun, merentang, berbelok, mengangkat, bergoyang, melengkung, memeluk, manarik, berayun, memutar dan mendorong. Keterampilan memproyeksi dan menerima menggerakan dan menangkap benda : menangkap, menarik, menggiring, melempar, menendang, memukul, melambungkan. Pengembangan keterampilan motorik ini memerlukan kesempatan untuk mengalami dan melakukan keterampilan tersebut. Kesempatan mengingat gerakan motorik yang sudah dilakukan untuk menyempurnaan dan penghalusan gerakan kesempatan untuk berlatih dalam waktu yang cukup.

Perkembangan motorik sebagai suatu bidang studi yang tidak secara lepas membahas aspek motorik saja. gerak manusia selalu berkaitan dengan aspek yang lain. Gerakan dipengaruhi oleh fisik dan aspek psikologis yang ada didalamnya. Misalnya orang yang ukuran fisiknya pendek-kecil cenderung lebih lincah dibanding dengan orang tinggi dan gemuk. Juga misalnya orang yang gizi makananya terpenuhi cenderung lebih besar kapasitas geraknya dibanding dengan orang yang gizi makananya kurang.

Keterampilan motorik halus adalah pengorganisasian penggunaan sekelompok otototot kecil seperti jari-jemari dan tangan yang sering membutuhkan kecermatan dan koordinasi mata dengan tangan, keterampilan yang mencakup pemanfaatan dengan alat-alat untuk bekerja dan obyek yang kecil atau pengontrolan terhadap mesin misalnya mengetik, menjahit dan lain-lain. Hal yang sama dikemukakan oleh Mahendra (1998), keterampilan motorik halus (fine motor skill) merupakan keterampilanketerampilan yang memerlukan kemampuan untuk mengontrol otot-otot kecil/ halus untuk mencapai pelaksanaan keterampilan yang berhasil.

Seorang anak lahir memiliki serangkaian refleks dasar. Dalam waktu yang relatif singkat, dengan kondisi yang sehat dan asupan nutrisi yang baik maka berat badan akan menjadi normal, seorang anak akan cepat memiliki kemampuan mengenali lingkungannya dan mulai mengembangkan kemampuan motoriknya. Inilah yang membuat anak menemukan duniannya melalui panca indranya seperti penglihatan, penciuman, sentuhan, dan pendengaran.

Pentingnya bagi anak kecil untuk berlatih menggunakan otot-otot besar saat terlibat dalam kegiatan motorik halus. Penundaan pengembangan koordinasi motorik kasar mungkin berdampak negatif pada perkembangan kemampuan motorik halus. Tetapi begitu anakanak biasa melakukan gerakan motorik halus, guru prasekolah sebaiknya mendorong mereka terlibat dalam sebuah jenis kegiatan manipulatif sehingga mereka bisa belajar dan lalu dan menerapkan kemampuan yang diperlukan untuk menggunakan tangan dan jemari dengan control dan tangkas (Bearty, 2013: 236).

Tujuan pengembangan motorik untuk anak usia TK (4-6 tahun) adalah anak dapat menunjukan kemampuam mengerakkan anggota tubuhnya dan terutama terjadinya koordinasi mata dan tangan sebagai persiapan untuk pengenalan. Sedangkan fungsi pengembangan motorik halus adalah mendukung aspek pengembangan aspek lainnya seperti kognitif dan bahasa serta sosial karena pada hakekatnya setiap pengembangan tidak dapat terpisah satu sama lain. Selain perkembangan motorik kasar yang begitu pesat, perkembangan motorik halus anak di usia ini pun semakin meningkat.

Kesiapan memasuki sekolah dasar bukanlah tujuan satu-satunya atau tujuan utama dari PAUD. Tujuan utama PAUD adalah menfasilitasi pertumbuhan dan perkembangan anak sedini mungkin yang meliputi aspek-aspek fisik, psikis dan sosial secara menyeluruh, yang merupakan hak anak. Dengan perkembangan itu, maka anak diharapkan lebih siap untuk belajar lebil lanjut, bukan hanya belajar (akademik di sekolah), melainkan belajar sosial, emosional, moral dan lain-lain pada lingkungan sosial, itulah tujuan utamanya.

Selama ini peneliti sebagai pendidik di Taman Kanak-kanak telah mencoba memberikan kegiatan pembelajaran untuk mengembangkan kemampuan motorik halus anak, akan tetapi peneliti mendapat suatu permasalahan yaitu masih rendahnya kemampuan motorik halus anak dalam menggerakkan jari tangan untuk kegiatan, seperti menggunting kertas dengan hasil guntingan yang lurus, menggambar gambar sederhana dan mewarnai, melipat kertas, 
mengisi pola dengan cara menempelkan bendabenda kecil, dan lain-lain.

Berdasarkan fenomena yang terjadi diatas peneliti simpulkan bahwa permasalahan ini terjadi disebabkan oleh beberapa hal yaitu: perkembangan motorik halus anak belum berkembang secara optimal, karena pembelajaran kegiatan menempel jarang atau kurang dilakukan.

Berdasarkan observasi awal di kelompok B menunjukkan bahwa dari jumlah 20 diantaranya anak laki-laki berjumlah 8 orang dan anak perempuan berjumlah 12 orang anak dan ada beberapa anak khususnya pada kelompok B dalam kemampuan menempel pada pola masih perlu dikembangkan dan ditingkatkan lagi. Saat anak diminta oleh guru untuk menempel pada pola, menggunting dengan benar, ada 12 anak dari 20 anak atau setara dengan $60 \%$ yang belum dapat menempel dengan rapi, 8 orang anak atau $40 \%$ yang menda-patkan nilai kategori BSB dan BSH dengan skor 4 dan 3. Sedangkan 12 anak mendapatkan nilai dengan kategori rata-rata mulai berkembang (MB) dan belum berkembang (BB) dengan skor 2 dan skor 1.

Rendahnya kemampuan motorik halus anak disebabkan oleh kurangnya penerapan pembelajaran kegiatan menem-pel pada pola di Kelompok B TK Negeri Melati Mekar Kecamatan Wolasi, dan jumlah antara anak dan tenaga pendidik tidak sebanding sehingga proses pembelajaran menjadi tidak efektif.

Menempel merupakan salah satu kegiatan yang dapat dilakukan untuk mengembangkan keterampilan motorik halus pada anak, menempel sering disebut kolase. Kegiatan menempel adalah salah satu kegiatan yang menarik minat anak-anak karena berkaitan dengan meletakkan dan merekatkan sesuatu sesuka mereka

Menempel merupakan proses terakhir dari kegiatan 3M yaitu menggunting, melipat dan menempel. Proses dalam menempel mempunyai tujuan motorik yang sangat nyata, karena dalam menempel potongan gambar diperlukan ketelitian, kesabaran, keterampilan dalam proses penempelan gambar. Untuk kegiatan menempelkan gambar telah disediakan tempat yang biasanya sudah ada batas-batas, yaitu ruangan kosong yang bentuknya sama dengan bentuk ruangan yang diwarnai.

Menempel merupakan proses terakhir dari kegiatan menggunting, dan melipat. Proses dalam menempel mempunyai tujuan motorik yang sangat nyata, karena dalam menempel potongan gambar diperlukan ketelitian, kesabaran, keterampilan dalam proses penempelan gambar. Untuk kegiatan menempelkan gambar telah disediakan tempat yang biasanya sudah ada batas-batas, yaitu ruangan kosong yang bentuknya sama dengan bentuk ruangan yang diwarnai. Proses kegiatan menempel untuk anak usia dini menekankan kebebasan anak untuk berkreasi.

\section{METODE}

Jenis penelitian yang digunakan adalah Penelitian Tindakan Kelas (Classroom Action Research). Penelitian tindakan kelas (PTK) adalah suatu bentuk penelitian yang bersifat reflektif dengan melakukan tindakan tertentu agar dapat memperbaiki/meningkatkan praktek pembelajaran di kelas secara lebih profesional, dengan tujuan perbaikan dan peningkatan layanan professional. guru dalam menangani proses pembelajaran (Yusdhitira, 2013:26).

Penelitian ini telah dilaksanakan pada semester genap di Taman Kanak-kanak Negeri Melati Mekar Kecamatan Wolasi Kabupaten Konawe Selatan. Waktu penelitian dilaksanakan pada bulan April 2016 semester genap tahun ajaran 2015/2016. Penelitian tindakan kelas ini dilakukan di Kelompok B Taman Kanak-kanak Negeri Melati Mekar dengan subyek penelitian ini adalah guru dan anak didik kelompok B dengan jumlah 20 anak, yang terdiri dari 8 anak laki- laki dan 12 anak perempuan.

Adapun faktor-faktor yang diteliti dan diamati dalam penelitian ini adalah sebagai berikut: (a) faktor guru, mengamati aktivitas guru dalam melaksanakan proses pembe-lajaran, tentang meningkatkan kemam-puan motorik halus anak di Kelompok B TK Negeri Melati Mekar, (b) faktor motorik halus anak: melihat aktivitas anak selama mengikuti proses pembelajaran tentang kemampuan motorik halus melalui kegiatan menempel.

Data yang diperoleh dari penelitian ini adalah data kualitatif dan data kuantitatif. Data kualitatif digunakan untuk menghimpun data tentang pelaksanaan proses pembelajaran yang dilaksanakan oleh guru. Data kualitatif diperoleh melalui lembar observasi. Sedangkan data kuantitatif diperoleh melalui lembar instrumen/evaluasi yang dilakukan pada setiap pertemuan dan diakhir siklus tindakan.

Sumber data dari penelitian ini adalah anak TK Negeri Melati Mekar khususnya Kelompok B, yaitu adalah data tentang 
kemampuan motorik halus anak dalam proses pembelajaran melalui kegiatan menempel pada pola. Selain itu data diperoleh melalui lembar observasi guru mengajar dan lembar obserbasi anak belajar.

Indikator kinerja dalam penelitian ini ditetapkan anak oleh TK Negeri Melati Mekar, yang terdiri dari indikator proses pembelajaran dan indikator hasil (nilai) anak didik. Proses pembelajaran melalui kegiatan menempel untuk meningkatkan kemampuan motorik halus anak dapat dikatakan terlaksana dengan baik apabila minimal keberhasilannya mencapai $\geq 75 \%$

Penilaian terhadap kemampuan motorik halus anak yang diperlihatkan melalui evaluasi mengacu pada pedoman pemberian nilai dalam satuan pendidikan Taman Kanak-kanak, yaitu bintang $(*)=$ Belum Berkembang $(\mathrm{BB})$ bintang $(* *)=$ Mulai Berkembang (MB), bintang $(* * *)$ $=$ Berkembang Sesuai Harapan (BSH), bintang $(* * * *)=$ Berkembansg Sangat Baik (BSB), (Depdiknas, 2004: 26).

\section{HASIL DAN PEMBAHASAN}

observasi mengajar guru sesuai dengan pedoman lembar observasi sebanyak 12 aspek yang diamati akan dicapai oleh guru. Pada siklus I skor yang dicapai oleh guru dari 12 aspek hanya 7 aspek setara dengan 58,3\% diantaranya: (1) guru mempersiapkan anak untuk belajar, (2) Guru menyiapkan bahan alat dan bahan pembelajara, (3) Guru menjelaskan tujuan pembelajaran/materi pembelajaran yang akan dilaksanakan, (4) Guru memandu anak dalam kegiatan menempel, (5) Guru meminta anak menempel mengikuti pola guru, (6) Guru meminta anak untuk menggunting dengan rapi, (7) Guru memberikan bimbingan kepada anak agar tidak keluar garis dalam kegiatan menempel, sedangkan yang tidak tercapai terdapat 5 aspek $(41,67 \%)$ diantaranya: (1) Guru tidak meminta anak menempel dengan koordinasi mata dan tangan (2) Guru tidak memantau anak dengan berkeliling dalam kelas saat anak sedang melakukan kegiatan pembelajaran, (3) Guru tidak mengadakan tanya jawab tentang kegiatan hari ini, (4) Guru tidak memberikan pesan-pesan yang terkandung dalam kegiatan menempel, (5) Guru tidak mengajak anak untuk menyanyikan lagu yang berhubungan dengan tema.

Lembar observasi aktivitas belajar anak pada siklus I yang dicapai anak adalah 7 aspek dari 10 aspek yang meliputi: (1) anak mempersiapkan diri untuk belajar, (2) Anak mendengarkan cerita guru dengan tenang tentang kegiatan menempel, (3) Anak menggunting dengan rapi dan mengikuti pola, (4) Anak menempel mengikuti pola guru, (5) Anak menempel dengan koordinasi mata dan tangan, (6) Anak terampil menggerakan, kelenturan tangan untuk menempel, (7) Anak memberi salam sebelum pulang. Sedangkan aspek yang tidak tercapai yaitu terdiri dari 3 aspek diantaranya: (1) Anak mengerjakan tugas dengan tertib, (2) Anak menyanyikan lagu yang berhubungan dengan tema, (3) Anak menjawab pertanyaan dengan benar. Dengan demikian persentase ketercapaian belajar anak tersebut sebesar $70 \%$ dan yang tidak tercapai $30 \%$.

Hasil kemampuan motorik halus anak pada siklus I dapat dilihat pada Tabel berikt ini.

Tabel 1. Nilai Klasikal pada Siklus I

\begin{tabular}{lcc}
\hline \multicolumn{1}{c}{ Kategori } & Jumlah & Persentase \\
\hline $\begin{array}{l}\text { Berkembang Sangat } \\
\text { Baik (BSB) }\end{array}$ & 4 & 20 \\
\hline $\begin{array}{l}\text { Berkembang Sesuai } \\
\text { Harapan (BSH) }\end{array}$ & 9 & 45 \\
\hline $\begin{array}{l}\text { Mulai Berkembang } \\
\text { (MB) }\end{array}$ & 7 & 35 \\
\hline $\begin{array}{l}\text { Belum Berkembang } \\
\text { (BB) }\end{array}$ & 0 & 0 \\
\hline \multicolumn{1}{c}{ Jumlah } & 20 & 100 \\
\hline
\end{tabular}

Berdasarkan hasil yang diperoleh pada Tabel 1 diatas terlihat bahwa secara klasikal meningkatkan kemampuan motorik halus anak di kelompok B Taman Kanak-Kanak Negeri Melati Mekar pada tahap evaluasi siklus I, ratarata anak memperoleh nilai bintang (***) atau Berkembang Sesuai Harapan (BSH) dengan persentase $45 \%$ yaitu 9 orang anak didik dari 20 orang anak secara keseluruhan. Nilai bintang empat $(* * * *)$ atau Berkembang Sangat Baik (BSB) dengan persentase $20 \%$ yaitu diperoleh 4 orang anak didik, untuk nilai bintang dua $(* *)$ atau Mulai Berkembang (MB) dengan persentase $35 \%$ yaitu diperoleh 7 orang anak didik. Berdasarkan hasil evaluasi tersebut, sebagian besar anak sudah dapat melaksanakan kegiatan dengan baik.

Hasil analisis observasi guru sesuai dengan lembar observasi sebanyak 12 aspek yang diamati harus dicapai oleh guru. Pada siklus II skor yang dicapai oleh guru dari 11 aspek hanya 10 aspek (91\%) diantaranya: (1) guru mempersiapkan anak untu belajar, (2) Guru mempersiapkan anak untuk belajar, (3) Guru 
menjelaskan tujuan pembelajaran/materi pembelajaran yang akan dilaksanakan, (4) Guru memandu anak dalam kegiatan menempel, (5) Guru meminta anak menempel mengikuti pola guru, (6) Guru meminta anak untuk menggunting dengan rapi, (7) Guru memberikan bimbingan kepada anak agar tidak keluar garis dalam kegiatan menempel, (8) Guru tidak meminta anak menempel dengan koordinasi mata dan tangan, (9) Guru tidak memantau anak dengan berkeliling dalam kelas saat anak sedang melakukan kegiatan pembelajaran, (10) Guru mengadakan tanya jawab tentang kegiatan hari ini, (11) Guru memberikan pesan-pesan yang terkandung dalam kegiatan menempel. Sedangkan yang tidak tercapai 1 aspek (5\%) yaitu guru tidak mengajak anak untuk menyanyikan lagu yang berhubungan dengan tema.

Analisis hasil aktivitas belajar anak sesuai dengan lembar observasi pada siklus II sebanyak 10 aspek yang diamati diharapkan dapat tercapai, namun yang tercapai sebanyak 9 aspek 90\% meliputi: (1) anak mempersiapkan diri untuk belajar, (2) Anak mendengarkan cerita guru dengan tenang tentang kegiatan menempel, (3) Anak menggunting dengan rapi dan mengikuti pola, (4) Anak menempel mengikuti pola guru, (5) Anak menempel dengan koordinasi mata dan tangan, (6) Anak terampil menggerakan, kelenturan tangan untuk menempel, (7) Anak memberi salam sebelum pulang. (8) anak mengerjakan tugas dengan tertib, (9) Anak menyanyikan lagu yang berhubungan dengan tema. Sedangkan yang tidak tercapai 1 aspek $10 \%$ yaitu: anak mengerjakan tugas dengan tertib.

Hasil kemampuan motorik halus anak pada siklus II dapat dilihat pada Tabel berikt ini.

Tabel 2. Nilai Klasikal pada Siklus II

\begin{tabular}{lcc}
\hline \multicolumn{1}{c}{ Kategori } & Jumlah & Persentase \\
\hline $\begin{array}{l}\text { Berkembang Sangat } \\
\text { Baik (BSB) }\end{array}$ & 6 & 30 \\
\hline $\begin{array}{l}\text { Berkembang Sesuai } \\
\text { Harapan (BSH) }\end{array}$ & 11 & 55 \\
\hline $\begin{array}{l}\text { Mulai Berkembang } \\
\text { (MB) }\end{array}$ & 3 & 15 \\
\hline $\begin{array}{l}\text { Belum Berkembang } \\
\text { (BB) }\end{array}$ & 0 & 0 \\
\hline \multicolumn{1}{c}{ Jumlah } & 20 & 100 \\
\hline
\end{tabular}

Berdasarkan data hasil perolehan nilai anak didik yang ditampilkan pada Tabel 2 di atas, maka dapat disimpulkan bahwa secara klasikal perolehan nilai anak didik dalam kegiatan meningkatkan kemampuan motorik halus anak melalui kegiatan menempel pada pola di kelompok B Taman Kanak Melati Mekar Kecamatan Wolasi mengalami peningkatan, karena tingkat keberhasilan anak didik yaitu sebesar $85 \%$. Anak didik yang memperoleh nilai bintang empat (****) atau Berkembang Sangat Baik (BSB) yaitu sebanyak 6 orang anak didik dengan persentase $30 \%$, nilai bintang tiga (***) atau Berkembang Sesuai Harapan (BSH) yaitu sebanyak 11 orang anak didik dengan persentase $55 \%$, untuk yang memperoleh nilai bintang dua (**) atau Mulai Berkembang (MB) yaitu sebanyak 2 orang anak didik dengan persentase $15 \%$. Walaupun masih terdapat anak didik yang memperoleh nilai bintang dua (**) atau Mulai Berkembang (MB) tetapi dapat dikatakan bahwa sebagian besar anak didik dipandang telah mampu menyelesaikan tugas-tugas yang telah ditetapkan sesuai dengan indikator penilaian dalam ini khususnya dalam pelaksanaan tindakan siklus II.

Setelah dilakukan perbaikan-perbaikan dalam siklus II, ternyata hasil yang diperoleh mengalami peningkatan yang cukup signifikan pada aspek kemampuan motorik halus anak. Berdasarkan data yang diperoleh pada siklus I dan siklus II, dapat diketahui perbandingan jumlah anak yang telah memiliki peningkatan kemampuan motorik halus anak dengan kriteria berkembang sangat baik (BSB) dan berkembang sesuai harapan (BSH), sebelum tindakan terdapat 9 anak yang memperoleh dengan kategori tuntas, setelah pekasanaan siklus I mengalami peningkatan menjadi 12 anak dan siklus II meningkat menjadi 17 anak.

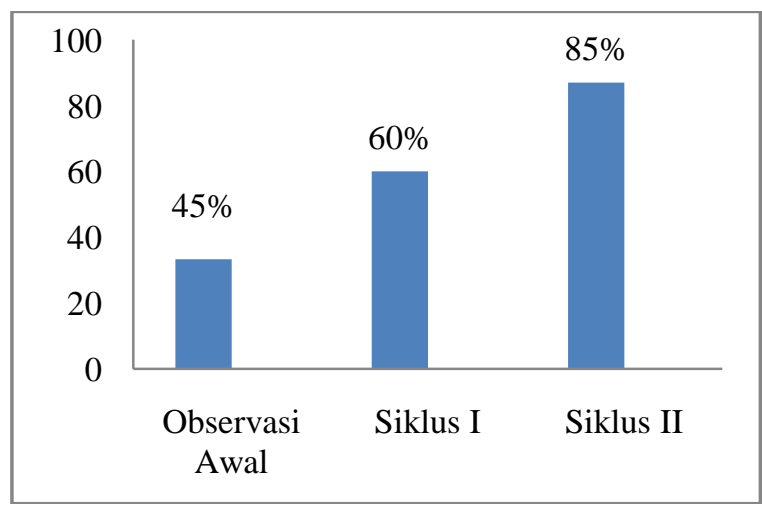

Gambar 1. Hasil Belajar Anak pada Observasi Awal, Siklus I dan Siklus II

Berdasarkan gambar 2 diatas dapat diketahui bahwa persentase perbandingan jumlah anak yang memiliki kemampuan motorik 
halus anak dengan kriteria Berkembang Sangat Baik (BSB) dan Berkembang Sesuai Harapan (BSH), pada kegiatan sebelum tindakan sebesar $45 \%$, setelah pelaksanaan tindakan siklus I mengalami peningkatan $60 \%$ dan pada siklus II meningkat menjadi $85 \%$. Dengan demikian dapat ditingkatkan melalui penggunaan media pola gambar.

\section{KESIMPULAN DAN SARAN}

Berdasarkan hasil belajar yang telah diperoleh anak pada kelompok B Taman Kanakkanak Negeri Melati Mekar Kecamatan Wolasi menunjukkan bahwa terdapat peningkatan kemampuan motorik halus anak melalui kegiatan menempel pada pola pada siklus I diperoleh persentase $60 \%$ atau 12 orang anak didik, dimana ada 2 orang anak didik yang memperoleh nilai bintang $(* * * *)$ atau Berkembang Sangat Baik (BSB) dan 10 orang anak didik yang memperoleh nilai bintang $(* * *)$ atau Berkembang Sesuai Harapan (BSB). Pada siklus II diperoleh persentase $85 \%$ atau 17 orang anak didik, dimana ada 3 orang anak didik yang memperoleh nilai bintang $(* * * *)$ atau Berkembang Sangat Baik (BSB) dan 14 orang anak didik yang memperoleh nilai bintang $(* * *)$ atau Berkembang Sesuai Harapan (BSB).

Saran yang peneliti dapat sampaiakan berdasarkan hasil penelitian ini yaitu agar kegiatan menempel pada pola dapat dijadikan sebagai kegiatan rutin yang dapat mengasah kemampuan motorik halus anak pada tema lainnya.

\section{DAFTAR PUSTAKA}

Beaty. Janice. 2013. Observasi Perkembangan Anak Usia Dini Edisi Ketujuh. Jakarta: PT Fajar Interpratama Mandiri.

Depdiknas. 2004. Pedoman Penilaian di Taman Kanak-kanak. Jakarta: Depdiknas.

Gordon, A. Mand Browne. K.W. 1985. Beginning and beyond fondation in early childhood education. New York: Delmer Publisher.

Hildebrand, Verna. 1986. Introduction to Early Childhood Education, 4th, ed. New York : Mac Millan Publishing Co.

Mahendra. 1998. Teori Belajar \& Pembelajaran Motorik. Bandung: Andira.
Retno, Widyani \& Danis, Widyastuti. 2008. Panduan Perkembangan Anak 0-1 Tahun. Jakarta: Puspa Swara.

Undang-Undang Nomor 20 Tahun 2003 tentang Sistem Pendidikan Nasional. Jakarta: Depdiknas.

Yudhistira, Dadang. 2013. Menulis Penelitian Tindakan Kelas yang APIK (Asli Perlu Ilmiah Konsisten). Jakarta: Grasin.

Yunanto. 2005. Sumber Belajar Anak Cerdas. Jakarta. Grasindo 